\title{
Temazepam Triggers the Release of Vasopressin into the Rat Hypothalamic Paraventricular Nucleus: Novel Insight into Benzodiazepine Action on Hypothalamic-Pituitary-Adrenocortical System Activity During Stress
}

\author{
Tobias Welt ${ }^{1,4}$, Mario Engelmann ${ }^{2,4}$, Ulrich Renner', Angelika Erhardt', Marianne B Müller', \\ Rainer Landgraf', Florian Holsboer' and Martin E Keck*, ${ }^{*, 1,3}$ \\ 'Max Planck Institute of Psychiatry, Munich, Germany; ${ }^{2}$ Institut für Medizinische Neurobiologie, Otto-von-Guericke-Universität Magdeburg, \\ Magdeburg, Germany; ${ }^{3}$ Division of Psychiatry Research, Psychiatric University Hospital Zurich, Zurich, Switzerland
}

\begin{abstract}
We investigated the influence of a representative classical benzodiazepine on the regulation of the hypothalamic-pituitary-adrenocortical (HPA) axis activity both under basal conditions and stress. Adult male Wistar rats were intravenously administered with temazepam (0.5, $\mathrm{I}$, and $3 \mathrm{mg} / \mathrm{kg}$ body weight) and plasma concentrations of corticotropin (ACTH) and vasopressin (AVP) were measured in blood samples collected via chronically implanted jugular venous catheters. Simultaneously, the release of AVP within the hypothalamic paraventricular nucleus (PVN) was monitored via microdialysis. Plasma AVP levels remained unaffected by the different treatment conditions. Temazepam blunted the stressor exposure-induced secretion of ACTH in a dose-dependent manner. Concurrently, and also in a dose-dependent manner temazepam enhanced the intra-PVN release of AVP, known to originate from magnocellular neurons of the hypothalamic neurohypophyseal system. Furthermore, temazepam did not affect the in vitro secretion of ACTH from the adenohypophyseal cells. Taken together, the results of this study suggest that temazepam modulates the central nervous regulation of the HPA axis by altering intra-PVN AVP release. An increasingly released AVP of magnocellular origin seems to provide a negative tonus on ACTH secretion most probably via inhibiting the release of ACTH secretagogues from the median eminence into hypophyseal portal blood.
\end{abstract}

Neuropsychopharmacology (2006) 3 I, 2573-2579. doi:I0. I038/sj.npp. I 30 I006; published online 4 January 2006

Keywords: vasopressin; temazepam; gamma-amino butyric acid; hypothalamic-pituitary-adrenocortical system; benzodiazepine; hypothalamic paraventricular nucelus

\section{INTRODUCTION}

Changes in hypothalamic-pituitary-adrenocortical (HPA) system regulation have repeatedly been demonstrated to be critically involved in the pathogenesis of affective disorders such as major depression (Keck and Holsboer, 2001; Keck et al, 2005). In fact, a restoration of normal HPA system function has been shown to be a prerequisite for remission (Holsboer, 2000). 'Classical' benzodiazepines are known to

\footnotetext{
*Correspondence: Dr ME Keck, Division of Psychiatry Research, Psychiatric University Hospital Zurich, Minervastr. 145, Zurich CH-8032, Switzerland, Tel: + 4 I 44 389|477, Fax: + 4 | 44 389|4|4, E-mail: keck@mpipsykl.mpg.de

${ }^{4}$ These authors contributed equally to the study.

Received 20 September 2005; revised 7 November 2005; accepted 8 November 2005

Online publication: I November 2005 at http://www.acnp.org/ citations/Npp I | | | 05050585/default.pdf
}

act in a sedative and anxiolytic manner but also to normalize the HPA axis activity (Schuckit et al, 1992; Korbonits et al, 1995). Among the signals which seem to contribute to HPA axis regulation at the level of the hypothalamus, vasopressin (AVP) seems to play an important role (Wotjak et al, 2002). AVP is synthesized not only in magnocellular neurons, which are part of the hypothalamic-neurohypophysial system (HNS), but also in parvocellular neurons of the paraventricular nucleus (PVN). The latter neurons project to the external layer of the median eminence, where it is released from nerve terminals in response to appropiate stimuli (eg physical stress) and enters fenestrated portal capillaries. Transported to the anterior pituitary, AVP then stimulates the secretion of corticotropin (ACTH) synergistically with corticotropinreleasing hormone (CRH) (Antoni, 1993). ACTH, in turn, triggers the release of cortisol/corticosterone (CORT) from the adrenal glands which mediates a variety of adaptive 
responses to stress. Previous studies investigating the effects of temazepam on HPA axis regulation relied on the measurement of ACTH and CORT in the general circulation and extrapolated the altered plasma levels to the putative underlying central effects. Korbonits et al (1995), for example reported an inhibition of the $\mathrm{CRH}$-induced release of ACTH and CORT in healthy volunteers, which was taken as evidence that temazepam acts via a reduction of hypothalamic AVP release.

The present study was designed to investigate the effects of different dosages of temazepam on HPA system regulation in male Wistar rats under basal conditions and in response to $5 \mathrm{~min}$ of forced swimming, a combined physical and emotional stressor. In vivo microdialysis was used to monitor the intrahypothalamic release patterns of AVP from magnocellular neurons in the PVN. Intra-PVN release of AVP into the extracellular compartment has been suggested to have an inhibitory effect on the secretion of ACTH from the anterior pituitary (Wotjak et al, 1996; Wotjak et al, 1998). To investigate simultaneous changes in the release patterns of ACTH and AVP into the peripheral blood, blood samples were taken via chronically implanted jugular venous catheters. Plasma ACTH reflects the activity of the central nerval components of the HPA axis, that is, the secretory activity of the parvocellular neurons, whereas plasma AVP reflects the activity of the HNS, that is, the activity of axon terminals of magnocellular neurons projecting to the posterior pituitary. We extended these studies by analyzing the influence of temazepam on both basal and stimulated ACTH release from primary rat anterior pituitary cell cultures to control for possible direct effects of the drug on corticotrope cells.

\section{MATERIALS AND METHODS}

\section{In Vivo Studies}

Animals. The animal studies were conducted in accordance with the Guide for Care and Use of Laboratory Animals of the Government of Bavaria and the guidelines of the NIH. The experiments were performed on young adult male Wistar rats ( $n=59 ; 3$ months old; $320 \pm 20 \mathrm{~g}$ body weight) that were housed in groups of six in the breeding unit of the Institute under standard laboratory conditions $(12 \mathrm{~h}$ light: $12 \mathrm{~h}$ dark cycle with lights on at $0700,22 \pm 1{ }^{\circ} \mathrm{C}, 60 \%$ humidity, pelleted food and water ad libitum) for at least 1 week after delivery from the supplier (Charles River, Sulzfeld, Germany).

Surgery. All surgical procedures were performed under halothane anesthesia and aseptic conditions (Keck et al, 2000, 2002).

Implantation of microdialysis probese. The implantation of microdialysis probes was essentially performed as described in detail elsewhere (Horn and Engelmann, 2001). Briefly, 3 days before the experiment, a U-shaped microdialysis probe (dialysis membrane: molecular cutoff of $18 \mathrm{kDa}$; Hemophan ${ }^{\mathrm{TM}}$, Gambro Dialysatoren, Hechingen, Germany) was implanted stereotaxically according to the atlas of Paxinos and Watson (Paxinos and Watson, 1986) with their tips aimed at the right PVN $(1.5 \mathrm{~mm}$ caudal to bregma, $1.8 \mathrm{~mm}$ lateral to midline, $8.9 \mathrm{~mm}$ beneath the surface of the skull, angle of $10^{\circ}$ to avoid sagital sinus damage). The probe was secured with dental cement to two stainless-steel screws inserted into the bone.

Implantation of jugular venous catheters. Immediately after implantation of the microdialysis probe, the jugular vein was chronically catheterized for subsequent blood sampling as described elsewhere (Keck et al, 2001). The catheter was exteriorized at the neck of the animal and filled with sterile saline containing gentamicin (30000 IU/rat; Gentamycin, Centravet, Bad Bentheim, Germany). Approximately $0.2 \mathrm{ml}$ of the gentamycin solution was also infused into the animal.

Forced swimming. The forced swimming apparatus consisted of a cylindrical Plexiglas tank that was $40 \mathrm{~cm}$ high and $18 \mathrm{~cm}$ in diameter. The cylinder was filled with tap water $\left(23^{\circ} \mathrm{C}\right)$ up to a level of $25 \mathrm{~cm}$. Rats were transferred to the Plexiglas tank from their home cages, forced to swim in the apparatus for $5 \mathrm{~min}$, gently dried with a towel and returned to their home cages. The water was changed after each animal. During forced swimming, the behavior was recorded and subsequently analyzed. The following parameters were measured (Wotjak et al, 1998): Struggling as the time spent in movements of the fore limbs with breaking the surface of the water (eg scratching along the wall). Swimming as duration spent in fore and hind limb movements without breaking the water's surface with the fore limbs. Floating, defined as the behavior during which the animal uses just enough limb movement to keep afloat, with no struggling in the trunk.

Experimental protocol. The animals were divided into the following groups (temazepam: $0.5 \mathrm{mg} / \mathrm{kg} n=13,1 \mathrm{mg} / \mathrm{kg}$ $n=14,3 \mathrm{mg} / \mathrm{kg} n=21$; vehicle $n=11)$. At 0700 on the experimental day, jugular venous catheters were connected via $50-\mathrm{cm}$ PE-50 tubing to plastic syringes filled with sterile heparinized saline $(30 \mathrm{IU} / \mathrm{ml}$; Heparin, Ratiopharm, Ulm, Germany). Simultaneously, microdialysis probes were connected to a microinfusion pump via PE-20 tubing and perfused with sterile Ringer's solution $(3.3 \mu \mathrm{l} / \mathrm{min})$ for $3 \mathrm{~h}$ without sampling to adapt to the equipment (Keck et al, 2000). To monitor intra-PVN release of AVP under basal conditions, after administration of temazepam or vehicle and in response to forced swimming, eight consecutive 30min microdialysates were sampled from the right PVN. Microdialysates were directly collected in Eppendorf tubes and immediately stored at $-80^{\circ} \mathrm{C}$ until measurement. During collection of the third microdialysis sample, temazepam or vehicle were administered intravenously. Animals were subjected to $5 \mathrm{~min}$ of forced swimming during the fifth dialysis period. To simultaneously monitor the release of ACTH and AVP into blood five blood samples were taken. Two samples were drawn during the second and fourth microdialysis period and another three 5, 15, and $60 \mathrm{~min}$ after forced swimming. Blood samples were collected in prechilled tubes containing EDTA and a protease inhibitor (10 $\mu \mathrm{l}$ aprotinin; Trasylol ${ }^{\mathrm{TM}}$, Bayer, Germany) and centrifuged ( $5 \mathrm{~min}, 4000$ r.p.m., $4^{\circ} \mathrm{C}$ ). Plasma samples were stored at $-20^{\circ} \mathrm{C}$ until measurement. Figure 1 illustrates the experimental protocol. 
a

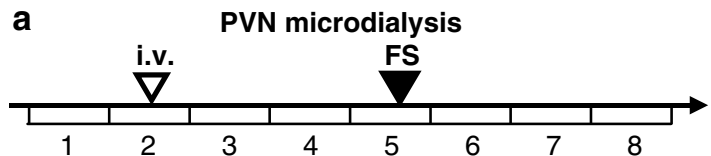

b

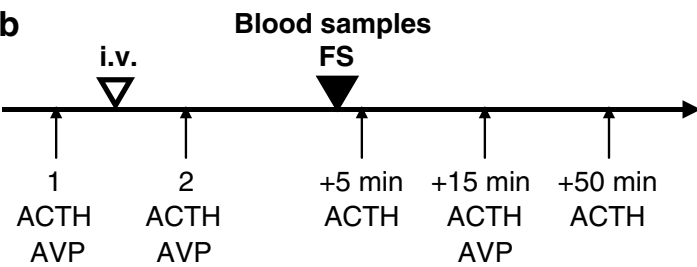

Figure I Experimental protocols. (a) PVN microdialysis and (b) jugular venous catheter blood sampling in relation to i.v. drug infusion (white triangle) and a 5 min forced swimming session (black triangle, FS). (a) Temazepam or vehicle were infused during collection of microdialysis sample 2; the 5 min of forced swimming session at $23^{\circ} \mathrm{C}$ was performed during collection of microdialysis sample 5. (b) Blood sample I was collected $45 \mathrm{~min}$ after beginning of the experiment, sample $245 \mathrm{~min}$ after application of temazepam or vehicle.

Postmortem analysis and histology. Animals were killed by an overdose of halothane at the end of the experiments. Brains were removed, frozen in prechilled $n$-methylbutane on dry ice and stored at $-80^{\circ} \mathrm{C}$. For histological analysis of the placement of the microdialysis probes, $25 \mu \mathrm{m}$ coronal cryostat sections were cut and stained with cresyl violet. Furthermore, we visually inspected in all animals the pituitary, adrenals, and other defined internal organs (thymus, etc) to ensure that all animals used were free from tumors.

Treatment of blood samples and radioimmunoassays. Plasma ACTH concentrations were measured using a commercially available radioimmunoassay kit according to the protocol of the manufacturer (Biochem, Freiburg, Germany; sensitivity: $<1.0 \mathrm{pg} / \mathrm{ml}$ ). The intra-assay coefficient of variation was $7 \%$. AVP was measured in lyophilized dialysates by a highly sensitive and selective radioimmunoassay (detection limit: $0.1 \mathrm{pg} / \mathrm{sample}$; crossreactivity of the antisera with other related peptides, including oxytocin, was $<0.7 \%$; for a detailed description see Landgraf and Neumann (2004).

Rat pituitary cell culture. For cell culture, material and reagents, except where stated, were purchased from Flow Laboratories (Meckenheim, Germany), Gibco BRL Life Technologies (Eggenstein, Germany), Seromed (Berlin, Germany), Sigma Chemical Co. (St Louis, MO, USA), Falcon (Heidelberg, Germany) or Nunc (Wiesbaden, Germany).

Primary rat pituitary cell cultures were established as previously described (Renner et al, 1995). In brief, pitutaries of male Sprague-Dawley rats were washed in preparation buffer $(137 \mathrm{mM} \mathrm{NaCl}, 5 \mathrm{mM} \mathrm{KCl}, 0.7 \mathrm{mM}$ $\mathrm{Na}_{2} \mathrm{HPO}_{4}, 15 \mathrm{mM}$ HEPES, $10 \mathrm{mM}$ glucose, $2.5 \mathrm{mg} / \mathrm{l}$ amphotericin- $\mathrm{B}, 10^{5} \mathrm{U} / \mathrm{l}$ penicillin/streptomycin, $\mathrm{pH} 7.3$ ) and cut into small pieces. The tissue fragments were mechanically and enzymatically dispersed in preparation buffer contain- ing $1000 \mathrm{U} / \mathrm{ml}$ collagenase (Worthington Biochemical Corp., Lakewood, NJ), $4 \mathrm{~g} / \mathrm{l} \mathrm{BSA}, 10 \mathrm{mg} / \mathrm{l}$ DNAase II, $1 \mathrm{~g} / \mathrm{l}$ trypein inhibitor, $2 \mathrm{~g} / \mathrm{l}$ hyaluronidase. The dispersed cells were washed by repetitive centrifugation and resuspension, and were then finally resuspended in DMEM culture medium (pH 7.3) supplemented with $10 \%$ heat-inactivated fetal calf serum, $2.2 \mathrm{~g} / 1 \mathrm{NaHCO}_{3}, 10 \mathrm{mM}$ HEPES, $2 \mathrm{mM}$ glutamine, $10 \mathrm{ml} / \mathrm{l}$ nonessential amino acids (Biochrom AG, Berlin, Germany), $10 \mathrm{ml} / \mathrm{l}$ MEM vitamins (Biochrom AG, Berlin, Germany), $5 \mathrm{mg} / \mathrm{l}$ insulin, $5 \mathrm{mg} / \mathrm{l}$ transferrin, $2.5 \mathrm{mg} / \mathrm{l}$ amphotericin-B, $10^{5} \mathrm{U} / \mathrm{l}$ penicillin/streptomycin, $20 \mu \mathrm{g} / \mathrm{l}$ sodium selenit, and $30 \mathrm{pM} \mathrm{T}_{3}$ (Henning, Germany). Cell viability was consistently over $90 \%$ as assessed by acridine orange/ethidium bromide staining. Cells were plated in 48 -well plates (100 000 cells/well in $0.5 \mathrm{ml}$ culture medium) and incubated for 2-3 days in a 5\% $\mathrm{CO}_{2}$ atmosphere at $37^{\circ} \mathrm{C}$ until the cells had attached to the plates.

Hormone stimulation in vitro. For ACTH stimulation, the initial culture medium was removed, the cells were washed with phosphate-buffered saline and stimulation medium (DMEM pH 7.3, supplemented with $0.5 \mathrm{~g} / \mathrm{l}$ BSA, $2.2 \mathrm{~g} / \mathrm{l}$ $\mathrm{NaHCO}_{3}, 10 \mathrm{mM}$ HEPES, $2 \mathrm{mM}$ glutamine, $30 \mathrm{mg} / \mathrm{l}$ ascorbic acid) was added. CRH, AVP, and temazepam were diluted in a small amount of stimulation medium and were applied to the cell cultures alone or in combination at various concentrations as indicated. After a stimulation period of $3 \mathrm{~h}, \mathrm{ACTH}$ was measured in the cell culture supernatants by RIA using an N-terminal-specific antibody as previously described (Arzt et al, 1993).

Statistics. Results are represented as means \pm SEM. Statistical analysis was performed with a statistical software package (GB-Stat version 6.0, Dynamic Microsystems, Silver Spring, MD, USA). Statistical significance was determined between groups by two-way analysis of variance (ANOVA) (treatment $\times$ time) for repeated measures. When appropriate, Fishers LSD test for post hoc comparison was used. A value of $p<0.05$ was considered statistically significant.

\section{RESULTS}

\section{In Vivo Studies}

Experimental animals were included in the statistical analysis of the intra-PVN release of AVP only if the microdialysis probes were found to be correctly localized within the right PVN and visual examination confirmed no organ pathology post mortem. In total, $54 \%$ of microdialysis probes were implanted correctly $(n=32)$. Furthermore, in some of the animals the jugular venous catheter failed to work properly which resulted in missing blood samples or blood samples with a reduced volume allowing the measurement of either AVP or ACTH only. These animals were also excluded from the statistical analysis of plasma ACTH and/or AVP values.

Figure 2a illustrates the impact of temazepam treatment on the intrahypothalamic PVN release of AVP. A two-way ANOVA revealed a significant treatment $\times$ time interaction effect $\left(\mathrm{F}_{21,196}=1.91 ; p<0.02\right)$. According to the subsequent post hoc analysis temazepam stimulated the release of this 


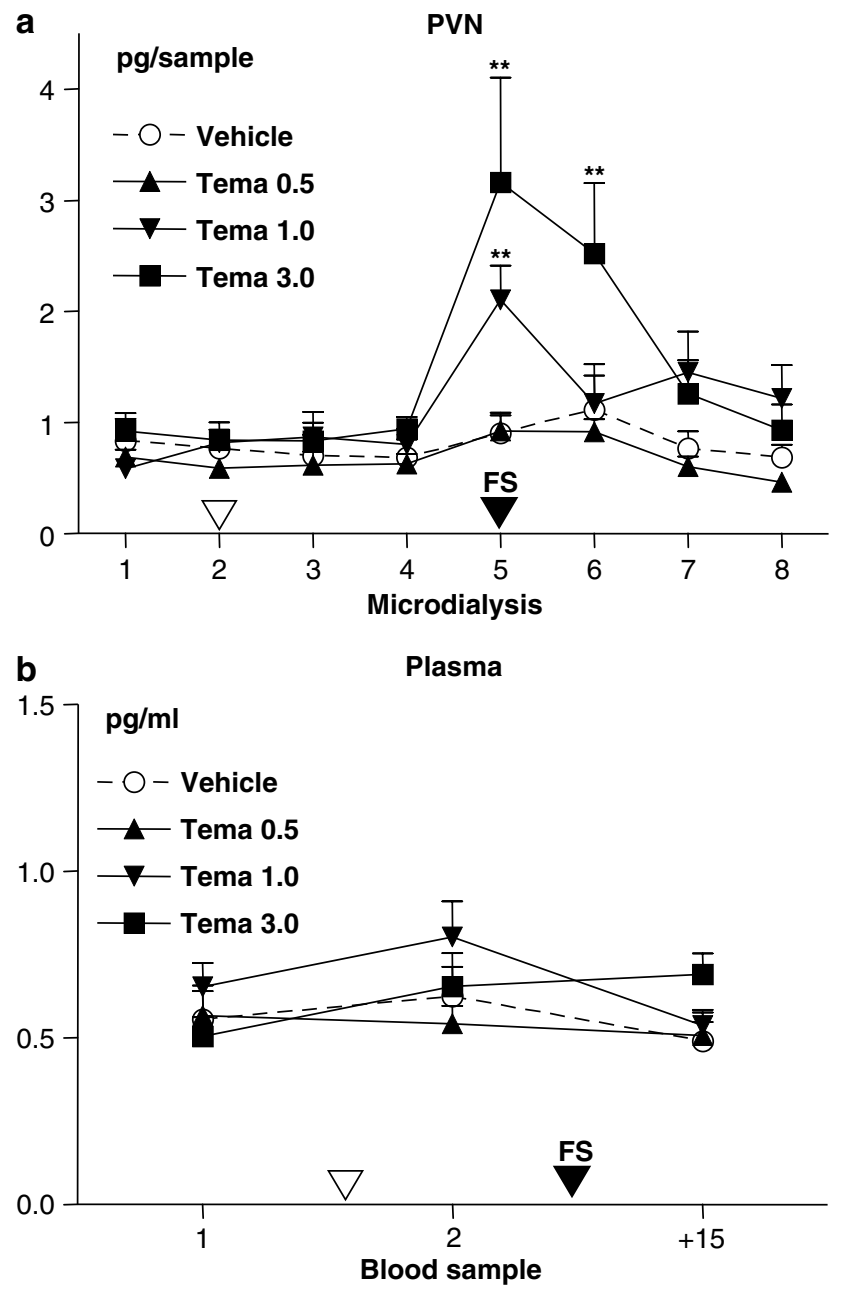

Figure 2 Temazepam increases dose dependently stress-induced intraPVN, but not plasma AVP release. Effects of intravenous infusion (white triangle) of $0.5 \mathrm{mg} / \mathrm{kg}(\mathrm{A}: n=8 ; \mathrm{B}: n=12), 1.0 \mathrm{mg} / \mathrm{kg}(\mathrm{A}: n=6 ; \mathrm{B}: n=9)$ and $3.0 \mathrm{mg} / \mathrm{kg}(\mathrm{A}: n=12 ; \mathrm{B}: n=18)$ temazepam (Tema) and vehicle (A: $n=6$; $B: n=9)$ as well as forced swimming (black triangle, FS) on the concentration of AVP (a) in consecutively collected 30-min microdialysates samples from the PVN and (b) in blood samples. Data are means + SEM. ** $p<0.0$ I vs the same sample of all other treatments and $p<0.01$ vs samples $1-4$ of the same treatment (Fisher's LSD post hoc test).

neuropeptide into the PVN in a dose-dependent manner. In contrast, as measured via jugular venous catheters, neither temazepam nor forced swimming had a statistically significant influence on the secretion of AVP from the posterior pituitary into the peripheral blood (treatment $x$ time interaction, $\mathrm{F}_{6,90}=1.17, p=0.33$; Figure $2 \mathrm{~b}$ ).

As shown in Figure 3, forced swimming caused a significant increase in plasma ACTH 5 and $15 \mathrm{~min}$ after stress (treatment $\times$ time interaction, $\mathrm{F}_{12,180}=6.05, p<0.0001$ ). A subsequent analysis provided evidence that temazepam treatment reduced the forced swimming-induced ACTH increase in a dose-dependent manner.

Analysis of the behavior monitored during forced swimming failed to provide significant differences between control animals and all dosages of temazepam used in either of the parameters measured (struggling, swimming, floating; $p>0.05$, data and statistics not shown).

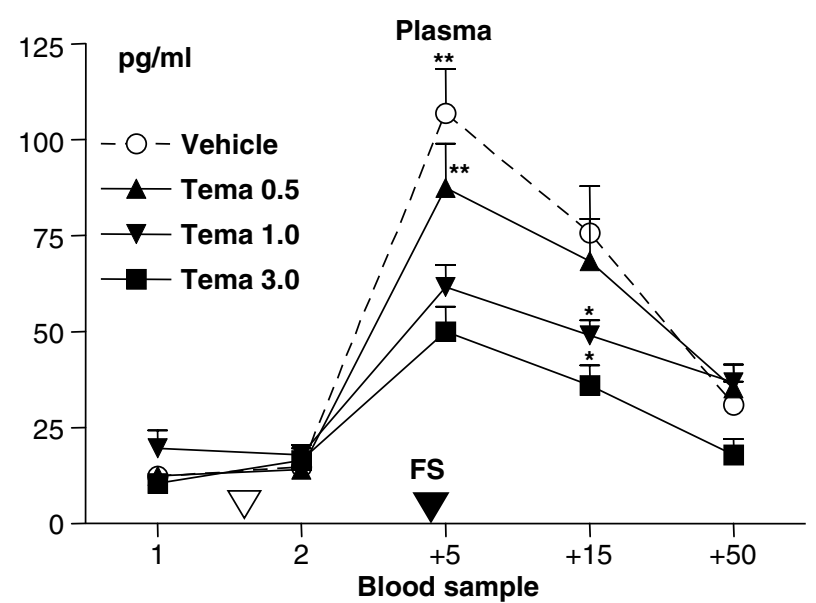

Figure 3 Temazepam reduces dose dependently stress-induced increase in plasma ACTH. Effects of intravenous infusion (white triangle) of $0.5 \mathrm{mg} / \mathrm{kg}(n=1 \mathrm{I}), 1.0 \mathrm{mg} / \mathrm{kg}(n=14)$, and $3.0 \mathrm{mg} / \mathrm{kg}(n=16)$ temazepam (Tema) and vehicle $(n=8)$ as well as forced swimming (black triangle, FS) on plasma ACTH. Data are means + SEM. $* p<0.05$ and $* * * 0.01$ vs the same sample of all other treatments; for all treatments: samples $+5 \mathrm{~min}$ and +15 min are $p<0.0$ I vs samples I and 2 of the same treatment (not shown, Fisher's LSD post hoc test).

Table I Effects of Temazepam on the Secretion of ACTH from Primary Rat Anterior Pituitary Cell Cultures

\begin{tabular}{|c|c|c|c|}
\hline & & CRH stimulation & AVP stimulation \\
\hline & Basal & $10 \mathrm{nM}$ & $1.0 \mu \mathrm{M}$ \\
\hline Basal & $8.51 \pm 0.44$ & $37.29 \pm 3.11$ & $15.21 \pm 1.22$ \\
\hline Temazepam $0.1 \mu \mathrm{M}$ & $7.92 \pm 0.46$ & $33.02 \pm 2.28$ & $|3.75 \pm 0.6|$ \\
\hline Temazepam $1.0 \mu \mathrm{M}$ & $7.85 \pm 0.24$ & $32.13 \pm 3.22$ & $14.50 \pm 0.97$ \\
\hline Temazepam $10 \mu \mathrm{M}$ & $7.97 \pm 0.81$ & $34.73 \pm 1.61$ & $13.92 \pm 1.04$ \\
\hline Propylenglycol & $8.97 \pm 0.37$ & $38.85 \pm 2.91$ & $|4.7| \pm 0.9 \mid$ \\
\hline
\end{tabular}

Data are means \pm SEM.

\section{In Vitro Studies}

A two-way ANOVA revealed that treatment with temazepam failed to significantly affect the basal and CRH- or AVPstimulated secretion of ACTH from primary rat anterior pituitary cell cultures. Also, treatment with propylenglycol did not affect ACTH secretion ( $p>0.05$, statistics not shown, Table 1).

\section{DISCUSSION}

The results of the present study demonstrate that temazepam affects the activity of the HPA axis in response to stressful stimuli. Furthermore, we show that the drug increased intra-PVN release of AVP while leaving plasma neuropeptide levels unchanged. As demonstrated by our in vitro studies, temazepam failed to significantly influence basal or CRH- or AVP-stimulated ACTH release from corticotrope cells. 
Temazepam blunted the activity of the HPA system in response to forced swimming in a dose-dependent manner. This is in line with previous studies which were predominantly based on the analysis of plasma corticosterone concentrations (Bruni et al, 1980; Schürmeyer et al, 1988; Owens et al, 1989, 1993; Kalogeras et al, 1990; Breier et al, 1991, 1992; Schuckit et al, 1992; Torpy et al, 1993, 1994; Rohrer et al, 1994; Korbonits et al, 1995; Arvat et al, 1998, 1999; Skelton et al, 2000). However, in contrast to corticosterone, changes in plasma ACTH can be directly linked to the secretory activity of the parvocellular neurons of the PVN: AVP and CRH are secreted as releasing hormones from these neurons into the pituitary portal blood to synergistically stimulate the secretion of ACTH from the anterior pituitary (Aguilera and Rabadan-Diehl, 2000; Aguilera et al, 2001). We, therefore, tested the possibility whether or not temazepam might directly act at the level of the anterior pituitary. In our hands, drug administration failed to alter ACTH secretion in vitro (Kalogeras et al, 1990). Thus, there is good evidence that the observed changes in ACTH release induced by temazepam after stressor exposure are due to an action of the benzodiazepine at the brain level. In this context, different lines of evidence suggest that temazepam might act on $\mathrm{GABA}_{\mathrm{A}}$ receptors expressed by parvocellular PVN neurons (Makara and Stark, 1974; Olschowka, 1987; Calogero et al, 1988; Meister et al, 1988; Hillhouse and Milton, 1989; Tsagarakis et al, 1990; Stotz-Potter et al, 1996). Unfortunately, there are no tools available to allow for measurement of portal blood concentrations of AVP and CRH in freely moving rats. Therefore, it is impossible to determine whether the effects of temazepam are based on a decreased secretion of AVP or $\mathrm{CRH}$ or both from parvocellular neurons into the portal blood.

Our results confirm that, at the defined time points, plasma AVP concentrations remain unchanged in response to forced swimming in control animals (Wotjak et al, 1998; Engelmann et al, 2000). Therefore, and given the various reports about a GABAergic control of the release of AVP from the posterior pituitary (Bisset and Chowdrey, 1980; Knepel et al, 1980; Iovino et al, 1982, 1983; Unger et al, 1983; Wible et al, 1985a, b; Chowdrey and Bisset, 1988; Chiodera et al, 1989; Roberts and Robinson, 1991; Magnusson and Meyerson, 1993), one would have expected to measure reduced plasma AVP levels after temazepam treatment. However, at the dosages used here, temazepam failed to influence plasma AVP concentrations under basal and stress conditions. This renders the possibility unlikely that AVP release from the axon terminals of magnocellular HNS neurons is inhibited by temazepam and is unlikely to have modulated the ACTH response observed after temazepam (Wotjak et al, 2002; Engelmann et al, 2004).

This is the first study using in vivo microdialysis to monitor the influence of temazepam on the intrahypothalamic release of AVP under basal conditions and in response to defined stressor exposure. In the extracellular fluid of the PVN, AVP is most likely derived from dendrites and somata of local magnocellular neurons (Wotjak et al, 2001). Temazepam enhanced the release of AVP within the PVN in a dose-dependent manner. This is particularly striking with respect to the suggested action of benzodiazepines to reinforce the inhibitory tonus of GABA on neuronal activity. Although magnocellular neurons have been shown to express $\mathrm{GABA}_{\mathrm{A}}$ receptors (Magnusson and Meyerson, 1993; Fenelon and Herbison, 1995; Fenelon et al, 1995) recent findings suggest that not only the peripheral but also intrahypothalamic release of AVP both under basal conditions and in response to forced swimming is predominantly controlled by the inhibitory amino-acid taurine rather than GABA (Engelmann et al, 2001). Thus, our data confirm that under both basal and stress conditions dendritic/somatic release of AVP is controlled by other (inhibitory) signals than GABA. Whether temazepam might have acted directly to alter taurine release or whether an action of the drug in more remote brain areas might have contributed to the increase in intra-PVN release of AVP requires further investigation.

Released from magnocellular neurons at the level of the hypothalamus, AVP has been proposed to act as a neuromodulator to facilitate the return of the HPA axis to basal levels via interaction with local V1 receptors (Wotjak et al, 1996, 2002). Therefore, the results of the present study suggest that temazepam affects HPA axis via at least two different mechanisms: having an inhibitory effect directly on parvocellular PVN neurons and, as shown here, by stimulation of the somatic dendritic release of AVP from magnocellular PVN neurons. This fits well with the hypothesis that at the level of the hypothalamus AVP of HNS origin seems to play an important role in controlling HPA axis activity (Engelmann et al, 2004). The dissociation between the increased release of AVP from somata and dendrites at the level of the PVN while the secretion from the axon terminals of the same neuronal population remained virtually unchanged has been reported earlier and illustrates a remarkable feature of magnocellular neurosecretoric control (Wotjak et al, 1998).

Although the dose dependency in the increase of intraPVN AVP mirrors the dose dependency in ACTH levels, a statistical analysis of ACTH and PVN AVP levels just failed to provide a significant correlation $\left(R^{2}=0.13 ; p=0.09\right)$. This may be due to the relatively low number of animals analyzed. However, the differences seen in both intra-PVN and ACTH response are unlikely to be due to an altered perception (and/or interpretation) of the stressor caused by temazepam as we failed to monitor differences in the acute behavioral stressor response. Thus, the present results encourage further studies about the role AVP plays after its release into the extracellular fluid of the PVN in response to temazepam treatment under stress conditions. This concerns in particular a detailed analysis of the receptor subtype via which AVP seems to act at the level of the PVN. Furthermore, subsequent studies should focus on the action of locally administered AVP antagonists to selectively interfere with the increasingly released neuropeptide in response to temazepam treatment and the consequences of this treatment on ACTH secretion. Based on the results of the present study, a partial restoration of the ACTH response by intra-PVN AVP antagonist treatment would be expected (Wotjak et al, 1996).

Taken together, we provide evidence that temazepam increases AVP release from magnocellular neurons in the $\mathrm{PVN}$ in response to defined stressor exposure in a dose dependent manner. This release into the extracellular fluid of the hypothalamus AVP has been suggested to facilitate 
the return of the HPA axis to basal levels. Thus, temazepam seems to act in a dual way to reduce HPA axis activity: directly via $\mathrm{GABA}_{\mathrm{A}}$ receptors and indirectly by increasing the intrahypothalamic concentrations of AVP. Furthermore, the results of the present study support the hypothesis that AVP acting at the level of the hypothalamus plays an important role in HPA axis regulation.

\section{REFERENCES}

Aguilera G, Rabadan-Diehl C (2000). Vasopressinergic regulation of the hypothalamic-pituitary-adrenal axis: implications for stress adaptation. Regul Pept 96: 23-29.

Aguilera G, Rabadan-Diehl C, Nikodemova M (2001). Regulation of pituitary corticotropin releasing hormone receptors. Peptides 22: 769-774.

Antoni FA (1993). Vasopressinergic control of pituitary adrenocorticotropin secretion comes of age. Front Neuroendocrinol 14 76-122.

Arvat E, Maccagno B, Ramunni J, Di Vito L, Gianotti L, Broglio F et al (1998). Effects of dexamethasone and alprazolam, a benzodiazepine, on the stimulatory effect of hexarelin, a synthetic GHRP, on ACTH, cortisol and GH secretion in humans. Neuroendocrinology 67: 310-316.

Arvat E, Maccagno B, Ramunni J, Di Vito L, Giordano R, Gianotti L et al (1999). The inhibitory effect of alprazolam, a benzodiazepine, overrides the stimulatory effect of metyrapone-induced lack of negative cortisol feedback on corticotroph secretion in humans. J Clin Endocrinol Metab 84: 2611-2615.

Arzt E, Buric R, Stelzer G, Stalla J, Sauer J, Renner U et al (1993). Interleukin involvement in anterior pituitary cell growth regulation: effects of IL-2 and IL-6. Endocrinology 132: 459-467.

Bisset GW, Chowdrey HS (1980). Central inhibition by GABA of the release of vasopressin by carbachol in the rat. Br J Pharmacol 70: 78.

Breier A, Davis O, Buchanan R, Listwak SJ, Holmes C, Pickar D et al (1992). Effects of alprazolam on pituitary-adrenal and catecholaminergic responses to metabolic stress in humans. Biol Psychiatr 32: 880-890.

Breier A, Davis OR, Buchanan RW (1991). Alprazolam attenuates metabolic stress-induced neuroendocrine and behavioral effects in humans. Psychopharmacology (Berlin) 104: 479-484.

Bruni G, Dal Pra P, Dotti MT, Segre G (1980). Plasma ACTH and cortisol levels in benzodiazepine treated rats. Pharmacol Res Commun 12: 163-175.

Calogero AE, Gallucci WT, Chrousos GP, Gold PW (1988). Interaction between GABAergic neurotransmission and rat hypothalamic corticotropin-releasing hormone secretion in vitro. Brain Res 463: 28-36.

Chiodera P, Gnudi A, Volpi R, Marchesi C, Marchesi M, Davoli D et al (1989). Effects of the GABAergic agent sodium valproate on the arginine vasopressin responses to hypertonic stimulation and upright posture in man. Clin Endocrinol (Oxford) 30: 389-395.

Chowdrey HS, Bisset GW (1988). Central inhibition by gammaaminobutyric acid of the release of vasopressin by carbachol in the rat. Br J Pharmacol 93: 349-356.

Engelmann M, Landgraf R, Wotjak CT (2004). The hypothalamicneurohypophysial system regulates the hypothalamic-pituitaryadrenal axis under stress: an old concept revisited. Front Neuroendocrinol 25: 132-149.

Engelmann M, Ludwig M, Singewald N, Ebner K, Sabatier N, Lubec $\mathrm{G}$ et al (2001). Taurine selectively modulates the secretory activity of vasopressin neurons in conscious rats. Eur J Neurosci 14: 1047-1055.

Engelmann M, Wotjak CT, Ebner K, Landgraf R (2000). Behavioural impact of intraseptally released vasopressin and oxytocin in rats. Exp Physiol 85: 125S-130S.
Fenelon VS, Herbison AE (1995). Characterisation of GABAA receptor gamma subunit expression by magnocellular neurones in rat hypothalamus. Brain Res Mol Brain Res 34: 45-56.

Fenelon VS, Sieghart W, Herbison AE (1995). Cellular localization and differential distribution of GABAA receptor subunit proteins and messenger RNAs within hypothalamic magnocellular neurons. Neuroscience 64: 1129-1143.

Hillhouse EW, Milton NG (1989). Effect of noradrenaline and gamma-aminobutyric acid on the secretion of corticotrophinreleasing factor-41 and arginine vasopressin from the rat hypothalamus in vitro. J Endocrinol 122: 719-723.

Holsboer F (2000). The corticosteroid receptor hypothesis of depression. Neuropsychopharmacology 23: 477-501.

Horn TF, Engelmann M (2001). In vivo microdialysis for nonapeptides in rat brain-practical guide. Methods 23: 41-53.

Iovino M, De Caro G, Massi M, Steardo L, Poenaru S (1983). Muscimol inhibits ADH release induced by hypertonic sodium chloride in rats. Pharmacol Biochem Behav 19: 335-338.

Iovino M, Steardo L, Poenaru S (1982). Inhibitory effect of centrally administered muscimol on increased plasma $\mathrm{ADH}$ concentration to angiotensin II. Neuroendocrinol Lett 4: 342-347.

Kalogeras KT, Calogero AE, Kuribayiashi T, Khan I, Gallucci WT, Kling MA et al (1990). In vitro and in vivo effects of the triazolobenzodiazepine alprazolam on hypothalamic-pituitaryadrenal function: pharmacological and clinical implications. J Clin Endocrinol Metab 70: 1462-1471.

Keck ME, Holsboer F (2001). Hyperactivity of CRH neuronal circuits as a target for therapeutic interventions in affective disorders. Peptides 22: 835-844.

Keck ME, Ohl F, Holsboer F, Müller MB (2005). Listening to mutant mice: a spotlight on the role of CRF/CRF receptor systems in affective disorders. Neurosci Biobehav Rev 29: 867-889.

Keck ME, Sillaber I, Ebner K, Welt T, Toschi N, Kaehler ST et al (2000). Acute transcranial magnetic stimulation of frontal brain regiones selectively modulates the release of vasopressin, biogenic amines and amino acids in the rat brain. Eur J Neurosci 12: $3713-3720$.

Keck ME, Welt T, Wigger S, Renner U, Engelmann M, Holsboer F et al (2001). The anxiolytic effect of the CRH1 receptor antagonist R121919 depends on innate emotionality in rats. Eur J Neurosci 13: 373-380.

Keck ME, Wigger A, Welt T, Müller MB, Gesing A, Reul JMHM et al (2002). Vasopressin mediates the response of the combined dexamethasone/CRH test in hyper-anxious rats: Implications for pathogenesis of affective disorders. Neuropsychopharmacology 26: 94-105.

Knepel W, Nutto D, Hertting G (1980). Evidence for the involvement of a GABA-mediated inhibition in the hypovolaemia-induced vasopressin release. Pflugers Arch 388: 177-183.

Korbonits M, Trainer PJ, Edwards R, Besser GM, Grossman AB (1995). Benzodiazepines attenuate the pituitary-adrenal responses to corticotrophin-releasing hormone in healthy volunteers, but not in patients with Cushing's syndrome. Clin Endocrinol (Oxford) 43: 29-35.

Landgraf R, Neumann I (2004). Vasopressin and oxytocin release within the brain: a dynamic concept of multiple and variable modes of neuropeptide communication. Front Neuroendocrinol 25: $150-176$

Magnusson AM, Meyerson BJ (1993). GABA-A agonist muscimol inhibits stimulated vasopressin release in the posterior pituitary of Sprague-Dawley, Wistar, Wistar-Kyoto and spontaneously hypertensive rats. Neuroendocrinology 58: 519-524.

Makara GB, Stark E (1974). Effects of gamma-aminobutyric acid (GABA) and GABA antagonist drugs on ACTH release. Neuroendocrinology 16: 178-190. 
Meister B, Hokfelt T, Geffard M, Oertel W (1988). Glutamic acid decarboxylase- and gamma-aminobutyric acid-like immunoreactivities in corticotropin-releasing factor-containing parvocellular neurons of the hypothalamic paraventricular nucleus. Neuroendocrinology 48: 516-526.

Olschowka JA (1987). GABAergic innervation of corticotropin releasing factor neurons in the rat paraventricular nucleus An electron microscopic immunocytochemical study. Soc Neurosci Abstr 13: 1656.

Owens MJ, Bissette G, Nemeroff CB (1989). Acute effects of alprazolam and adinazolam on the concentrations of corticotropin-releasing factor in the rat brain. Synapse 4: 196-202.

Owens MJ, Vargas MA, Nemeroff CB (1993). The effects of alprazolam on corticotropin-releasing factor neurons in the rat brain: implications for a role for CRF in the pathogenesis of anxiety disorders. J Psychiatr Res 27(Suppl 1): 209-220.

Paxinos G, Watson C (1986). The Rat Brain in Stereotaxic Coordinates. Academic Press: Sydney.

Renner U, Newton CJ, Pagotto U, Sauer J, Arzt E, Stalla GK (1995). Involvement of interleukin-1 and interleukin-1 receptor antagonist in rat pituitary cell growth regulation. Endocrinology 136: 3186-3193.

Roberts MM, Robinson AG (1991). The GABA agonist muscimol reduces vasopressin synthesis and release. Soc Neurosci Abstr 17: 1187.

Rohrer T, von Richthofen V, Schulz C, Beyer J, Lehnert H (1994). The stress-, but not corticotropin-releasing hormone-induced activation of the pituitary-adrenal axis in man is blocked by alprazolam. Horm Metab Res 26: 200-206.

Schuckit MA, Hauger R, Klein JL (1992). Adrenocorticotropin hormone response to diazepam in healthy young men. Biol Psychiatr 31: 661-669.

Schürmeyer TH, Tomai TP, Steinbach H, von zur Mühlen A, Gold PW (1988). Pituitary and adrenal responses to insulin induced hypoglycemia and to $\mathrm{CRH}$ are modulated by anxiolytic pretreatment in man. In: D'Agata R, Chrousos GP (eds). Recent Advances in Adrenal Regulation and Function. Raven Press: New York. pp 285-291.

Skelton KH, Nemeroff CB, Knight DL, Owens MJ (2000). Chronic administration of the triazolobenzodiazepine alprazolam produces opposite effects on corticotropin-releasing factor and urocortin neuronal systems. J Neurosci 20: 1240-1248.

Stotz-Potter EH, Morin SM, DiMicco JA (1996). Effect of microinjection of muscimol into the dorsomedial or paraven- tricular hypothalamic nucleus on air stress-induced neuroendocrine and cardiovascular changes in rats. Brain Res 742: 219-224.

Torpy DJ, Grice JE, Hockings GI, Walters MM, Crosbie GV, Jackson RV (1993). Alprazolam blocks the naloxone-stimulated hypothalamo-pituitary-adrenal axis in man. J Clin Endocrinol Metab 76: 388-391.

Torpy DJ, Grice JE, Hockings GI, Walters MM, Crosbie GV, Jackson RV (1994). Alprazolam attenuates vasopressin-stimulated adrenocorticotropin and cortisol release: evidence for synergy between vasopressin and corticotropin-releasing hormone in humans. J Clin Endocrinol Metab 79: 140-144.

Tsagarakis S, Rees LH, Besser GM, Grossman AB (1990). Gammaaminobutyric acid modulation of corticotropin-releasing factor41 secretion from the rat hypothalamus in vitro. J Neuroendocrinol 2: 221-224.

Unger T, Bles F, Ganten D, Lang RE, Rettig R, Schwab NA (1983). Gabaergic stimulation inhibits central actions of angiotensin II: pressor responses, drinking and release of vasopressin. Eur $J$ Pharmacol 90: 1-9.

Wible Jr JH, Zerbe RL, DiMicco JA (1985a). Benzodiazepine receptors modulate circulating plasma vasopressin concentration. Brain Res 359: 368-370.

Wible Jr JH, Zerbe RL, DiMicco JA (1985b). Stimulation of vasopressin release by gamma-aminobutyric acid antagonists in spinal cord transected rats. J Pharmacol Exp Ther 234: 378-385.

Wotjak CT, Ganster J, Kohl G, Holsboer F, Landgraf R, Engelmann M (1998). Dissociated central and peripheral release of vasopressin, but not oxytocin, in response to repeated swim stress: new insights into the secretory capacities of peptidergic neurons. Neuroscience 85: 1209-1222.

Wotjak CT, Kubota M, Kohl G, Landgraf R (1996). Release of vasopressin from supraoptic neurons within the median eminence in vivo. A combined microdialysis and push-pull perfusion study in the rat. Brain Res 726: 237-241.

Wotjak CT, Ludwig M, Ebner K, Russell JA, Singewald N, Landgraf $\mathrm{R}$ et al (2002). Vasopressin from hypothalamic magnocellular neurons has opposite actions at the adenohypophysis and in the supraoptic nucleus on ACTH secretion. Eur J Neurosci 16: 477-485.

Wotjak CT, Naruo T, Muraoka S, Simchen R, Landgraf R, Engelmann $M$ (2001). Forced swimming stimulates the expression of vasopressin and oxytocin in magnocellular neurons of the rat hypothalamic paraventricular nucleus. Eur J Neurosci 13: 2273-2281. 